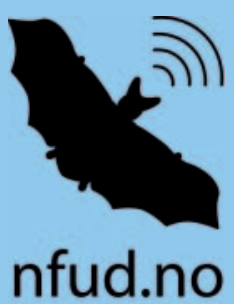

\section{Akuttmedisinsk ultralyd på frammarsj}

I forbindelse med opprettelsen av spesialiteten i akutt- og mottaksmedisin har man fått økt fokus på akuttmedisinsk ultralyd, ofte betegnet Point-ofcare-ultrasound (POCUS). Det anbefalte ultralydkurset for den nye spesialiteten har blitt meget populært og ettertraktet selv innen andre fagområder.

Fokusert akuttmedisinsk ultralyd har som formål å rettlede utredning og gi svar på konkrete akuttmedisinske problemstillinger omkring pasienter i den akutte settingen. Den fokuserte akuttmedisinske ultralyden er et supplement til den akutte kliniske undersøkelsen av pasienten. Den har ikke som mål å erstatte eller overta en grundig og systematisk ultrasonografisk undersøkelse utført ved en radiologisk avdeling eller en fullverdig ekkokardiologisk undersøkelse gjennomført av en kardiolog. Akuttmedisinsk ultralyd skal brukes som et klinisk verktøy og vil primært understøtte eller avkrefte differensialdiagnostiske betraktninger i den initiale vurderingen av en akutt syk eller skadet pasient. Undersøkelsen blir ofte utført under suboptimale forhold og under tidspress. Akuttmedisinsk ultralyd kan blant annet benyttes ved resuscitering, diagnostikk, symptomutredning og prosedyrer både prehospitalt, på legevakt, i primærhelsetjenesten, i akuttmottaket og $\mathrm{i}$ intensivavdelinger.

Den nye spesialiteten innen akutt- og mottaksmedisin krever at alle utdannede akuttleger har god kunnskap i bruk av fokusert akuttmedisinsk ultralyd. Akuttlegene skal nemlig være spesialister på vurdering og sortering av akutte pasienter, og dette inkluderer bruk av fokusert akuttmedisinsk ultralyd. Høsten 2018 ble det første anbefalte kurset "Ultralyd i akuttmedisin» gjennomført i henhold til den nye spesialiststrukturen for legeutdanningen. Kurset gjennomføres to ganger $\mathrm{i}$ året, men etterspørselen er så stor at det vil være behov for flere kurs fremover.

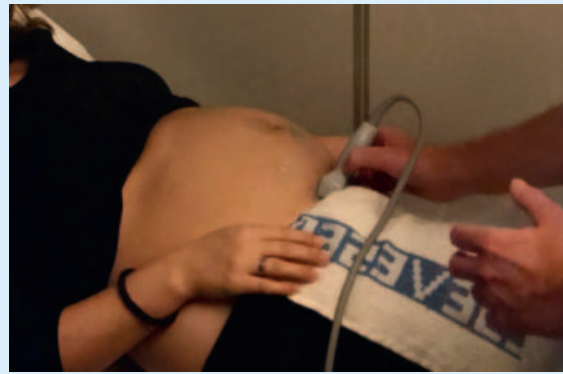

Kurset er et praktisk kurs som går over to hele dager. Deltakerne deles inn i smågrupper som roterer på fem forskjellige stasjoner hver dag. Etter en liten intro i tematikken på de ulike stasjonene vil deltakerne få praktisk trening i bruk av ultralyd på friske markører. Kurset tar sikte på blant annet å dekke læringsmål for leger i akutt- og mottaksmedisin, men også en rekke krav til kompetanse innen indremedisin. Leger i spesialisering innen andre fagområder som allmennmedisin, kirurgi og anestesiologi vil også ha nytte av dette praktiske ultralydkurset.

Det er ønskelig at mest mulig av kurset benyttes til hands-on trening slik at det forventes at deltakerne har tilegnet seg basalkunnskap før man møter til kurset. Etter dette kurset skal deltakerne ha kunnskap om basal bruk av fokusert akuttmedisinsk ultralyd, gjenkjenne åpenbar patologi ved målrettet ultralyd av hjertet, bruk av ultralyd ved traume eller sjokktilstander og relevante bruksområder for fokusert ultralyd i den akutte settingen. Alle deltakerne får tilsendt en informasjonsbrosjyre, samt gitt tilgang til faglige ressurser på internett. Kurset gir en innføring i point-of-care ultralyd med fokus på konkrete spørsmålsstillinger. Deltakerne skal kunne svare på kliniske spørsmål inkludert: Er det fri væske i buken? Er det utvidet nyrebekken? Er det forstørret hovedpulsåre? Er lungen kollapset? Er høyre side av hjertet forstørret?

Kurset avholdes ved St. Olavs hospital og gjennomføres av Mottaksavdelingen i samar-
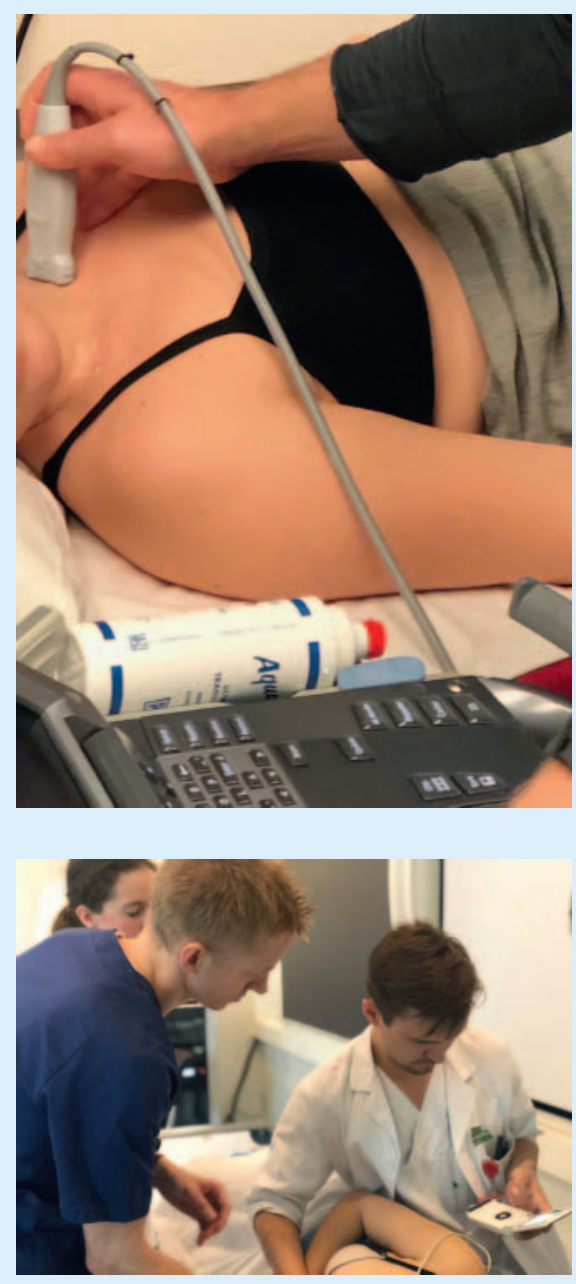

beid med andre fagområder. Kursleder er Lars Petter Bjørnsen som også er spesialist innen akutt- og mottaksmedisin. Deltakerne har gitt gode tilbakemeldinger på kurset og den store søkermassen viser at behovet er stort. Det er likevel viktig å at kvantitet ikke går på bekostning av kvalitet. Det er avgjørende at man har et optimalt antall kursdeltakere slik at man sikrer best mulig læringsutbytte.

Kurset er blitt en bærebjelke i akuttmedisinsk ultralyd. Ultralyd vil bare bli mer vanlig ved vurdering av pasienter og man kan med trygghet si at ultralydapparatet definitivt har tatt over for stetoskopet. 